\title{
Skin and Soft Tissue Infections Among the Diabetic Patients in Faridpur, Bangladesh
}

\author{
M D Arifin Khan ${ }^{1}$,Nusrat Jahan Shifa ${ }^{1}$ and Hamida Khanum ${ }^{2,3 *}$ \\ ${ }^{1}$ City of Osh, St. Sargalchaeva, 30/2, Kyrgyzstan, Bangladesh \\ ${ }^{2}$ Department of Public Health, American International University Bangladesh (AIUB), Bangladesh \\ ${ }^{3}$ Parasitology Branch, Department of Zoology, University of Dhaka, Bangladesh \\ *Corresponding author: Hamida Khanum, Professor, Department of Zoology, University of Dhaka, Bangladesh
}

\section{ARTICLE INFO}

Received: 幽 July 28, 2021

Published: 慧 August 09, 2021

Citation: MD Arifin Khan, Nusrat Jahan Shifa, Hamida Khanum. Skin and Soft Tissue Infections Among the Diabetic Patients in Faridpur, Bangladesh. Biomed J Sci \& Tech Res 38(1)-2021. BJSTR. MS.ID.006081.

Keywords: Skin and Soft Tissue Infection; Age; Prevention; Diabetic Patients

\begin{abstract}
Diabetic is now a day's most prevalent endocrine disorder; the number of occurrences increases day by day. In our country the new case of diabetic mellitus is remarkably increases in every year. Due to the pathophysiology of this disease, diabetic patient is more susceptible to infection, and they are more porn to develop complicated skin and soft tissue infections. The study was conducted among the diabetic patients in Faridpur Diabetic Association Medical College from April to September 2019. The present study has been done on the skin and soft tissue infections among the diabetic patients in Faridpur district. Among the respondent the highest percentage of the respondent's sufferings from type- 2 diabetic mellitus about (81.8 \%), (14.9\%) sufferings from type1 diabetic mellitus. Out of 121 respondents, 60 (49.6\%) were male and 61 (50.4\%) were females. Among the respondent the highest percentage of the respondents are not suffering from skin and soft tissue infection (73.6\%), only $26.4 \%$ are sufferings from skin and soft tissue infection. The incidence of skin and soft tissue infection was relatively more frequent among the patients whose blood glucose level was poorly controlled and uncontrolled.
\end{abstract}

\section{Introduction and Background}

Diabetes was one of the first described [1] which is a heterogeneous group of diseases characterized by chronic elevation of glucose in the blood. Diabetes affects some 300 million people world-wide and is on the increase. Chronic exposure to high blood glucose is a leading cause of renal failure, visual loss and a range of other types of tissue damage [2]. About 422 million people have diabetes worldwide [3] up from an estimated 382 million people in 2013 [4]. In 2014, the International Diabetes Federation (IDF) estimated that diabetes resulted in 4.9 million deaths worldwide, [5] where more than $80 \%$ of diabetic deaths occured [6-10]. Approximately $85 \%$ of those with diabetes; they are usually older, but it is increasingly diagnosed in children and adolescents. Type 2 diabetes is associated with excess body weight and physical inactivity [11]. In 2013, WHO stated that early diagnosis can be accomplished through relatively inexpensive blood testing.
Impetigo and cellulites and chronic skin ulcers are associated with diabetics which are: Streptococcus group A, Staphylococcus aurous, anaerobic oral flora (Prevotella, Fusobacterium and Peptostreptococcus spp.) Around oral area and head and neck Colonic flora: Enterobacteriaceae and anaerobes (i.e. Escherichia coli and Bacteroides fragilis group) around rectum and lower extremity Necrotizing fasciitis, Streptococcus group A (rarely also groups C or E), Staphylococcus aurous, Enterobacteriaceae. Enteric or oral anaerobes cause Gas gangrene and crepitus cellulites Clostridium perfringens and other Clostridium species, Progressive bacterial gangrene-Peptostreptococcus spp, Microaerophilic streptococci, Proteus spp, Myositis-Staphylococcus aureus, Streptococcus groups A, $B, C$ and $G$, Enterobacteriaceae, Yersinia entercolitica, Pseudomonas spp.; Aeromonas spp. Clostridium spp, Peptostreptococcus spp. Bacteroides spp [12]. 
Necrotizing fasciitis: Necrotizing fasciitis (NF) is a rapidly progressive inflammatory infection of the fascia, with secondary necrosis of the subcutaneous tissues. The speed of spread is directly proportional to the thickness of the subcutaneous layer. The perineum, trunk, abdomen and upper extremities are most commonly involved in Necrotizing fasciitis [13]. In soft-tissue infections, foot infections are the most common soft tissue infections in patients with diabetes. In DM, fasciitis is characterized by poly-microbial growth, with single anaerobic and multiple aerobic microorganisms [14,15].

Fungal and yeast infections: In diabetic individuals, mycotic infections might elevate the risk of manifesting diabetic foot syndrome [16]. Patients with improperly controlled diabetes disease are more prone to Mucocutaneous Candida infections. Perleche remains atypical warning of diabetes onset in children [17]. Recent studies have shown a statistically significant relationship between the most common dermatophyte infections like Epidermophyton floccosum and Trichophyton mentagrophytes, Trubrum with diabetes [18].

\section{Viral Infections}

Since long time, viruses have been suggested as a potential environmental trigger for DM (typically type-1 diabetes). Viruses belonging to the Enterovirus genus have the capacity to initiate and/or accelerate islet autoimmunity but cannot fully explain the etiology as a sole environmental trigger [19]. In the present investigation, the main objective was

a) Dentification of skin diseases including the fungal and bacterial infections among the diabetic patients in DAMCH.

b) Prevalence of skin diseases in different age and sexes groups,

c) The prevalence of skin and soft tissue infections in earlier diagnosed age group and long-standing diabetic patients and

d) Variations of prevalence of skin and soft tissue infections among the different type of diabetic patients. sand muscular.

Justification of this study: Skin and soft-tissue infections (SSTIs) are common reasons to seek medical care in the inpatient and outpatient settings. There were an estimated 869,800 hospital admissions in the hospitals for SSTIs in 2004 [20]. Several investigations have noted that the incidence of SSTIs is increasing in both the inpatient and outpatient settings in the U.S. during the first decade of the $21^{\text {st }}$ Century, with increases of $29 \%$ in the inpatient setting over a 4-year period and $50 \%$ in the outpatient setting over an 8-year period [21].

\section{Materials and Methods}

The study was conducted at Diabetic Association Medical College Hospital Faridpur. This study period was from April 2017 to September 2019). The study population will be all diabetic patient who admit in this hospital. A pretested semi-structured interview questionnaire with both, open-ended and closed-ended was be used to collect data. The statistical package for social sciences (SPSS) version 22.0 will be used to analyze the data. Obtained data will be evaluated by frequency and percentages ratios, Chi-square (x2), logistic regression analyses etc.

\section{Data Collection}

Face-to-face interview was taken using the questionnaire. Respondents was provided a detailed explanation of each question in the local language.

\section{Data Processing and Analysis:}

At the end of each day of data collection, each questionnaire was checked whether the questionnaire is filled completely and consistently. Data cleaning and editing was done and missed values statistically handled to help address concerns caused by incomplete data using SPSS statistical package. Data analysis was done on the basis of the research question and the objectives. The statistical package for social sciences (SPSS) version 22.0 was used to analyze the data. Obtained data was evaluated by frequency and percentages ratios, Chi-square ( $\mathrm{x} 2$ ), logistic regression analyses etc. Different types of graphs, figures and tables were summarizing the data visually. Testing was be done using the 0.05 level of significance.

\section{Results}

Out of 121 respondent 60 (49.6) were male respondent and $61(50.4 \%)$ were female respondent (Table 1). The participation of the female respondents was higher than the male respondent. Among the respondent the highest percentage of the respondent were around $46-55$ years old (31.4\%) following by the more than 56 years old (29.8\%),36-45 years age about $19 \%$, age $26-35$ years age was about $13 \%$ and 16-25 years old 6.6\% (Figure 1) (Tables $2 \& 3)$. Among the respondent the highest percentage were used to take oral medication, $36.40 \%$ insulin, $14 \%$ through exercise and $7.40 \%$ controlled only by diet control (Figure 2). According to Table 2, practiced mild exercise 53.7\%, $35.5 \%$ moderate exercise, 2.5 $\%$ did heavy exercise and 10 (8.3\%) without exercise Among the respondent the highest percentage of the respondents sufferings for 2-4 years about $39.7 \%, 30.6 \%$ for 5- 10 years, 15.7 are newly diagnosed case and $14 \%$ up to 10 years (Figure 3 ). 


\section{Different age group of respondents}

\#15- 25 years $\square 26$ - 35 years $\square 36$ - 45 years $\square 46$ - 55 years

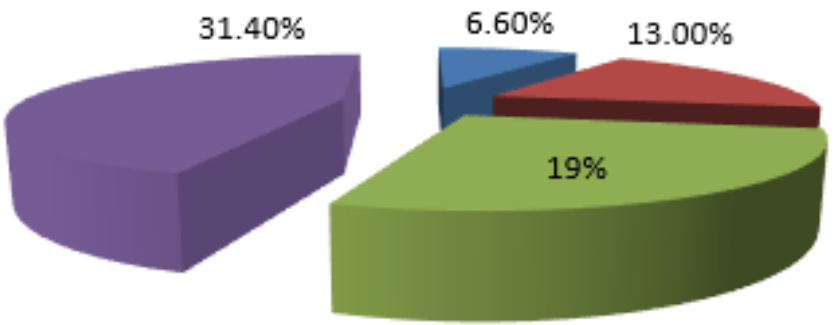

Figure 1: percentages of different age group of respondents.

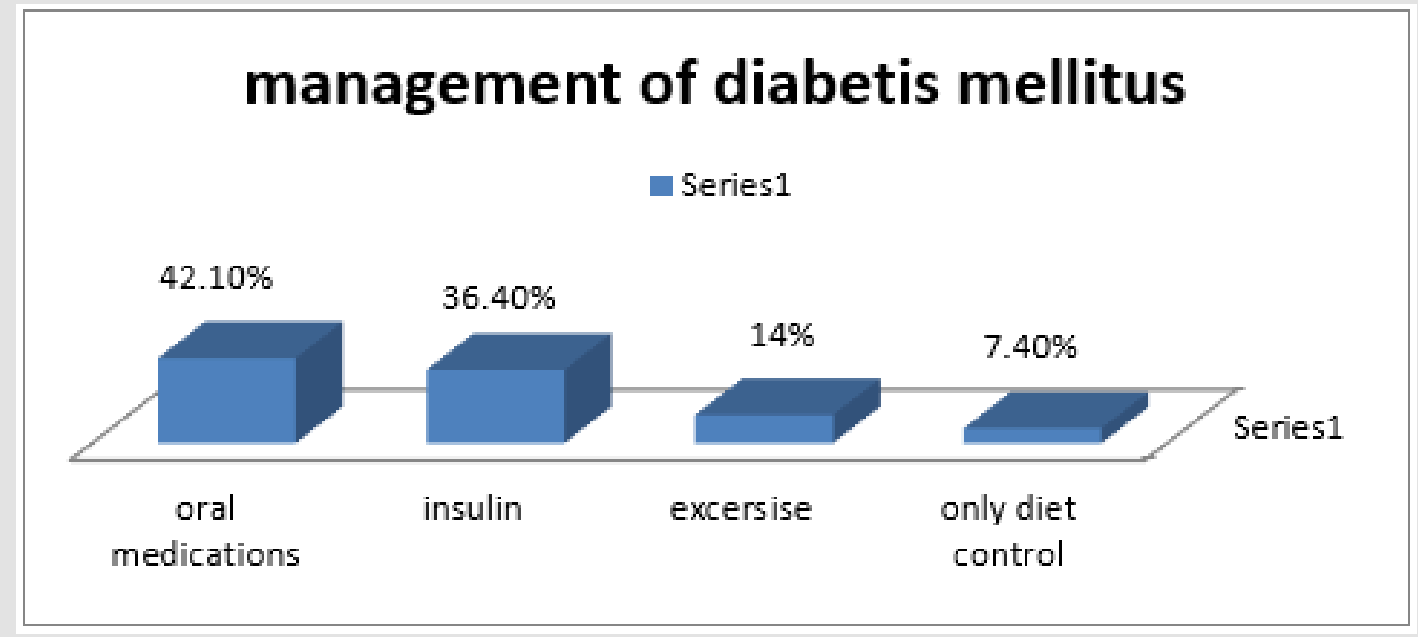

Figure 2: Management of diabetic by different practices.

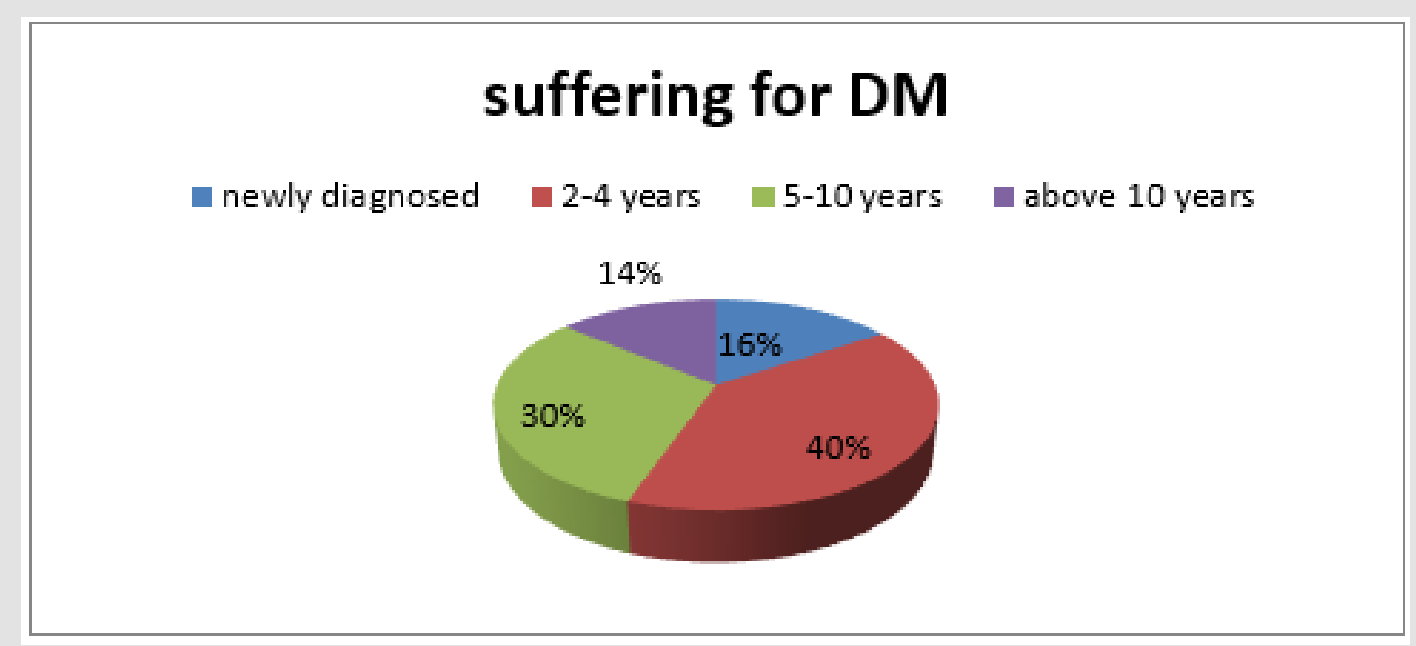

Figure 3: Respondents suffering from diabetic mellitus. 
Table 1: Percentages of male and female among respondents.

\begin{tabular}{|c|c|c|c|c|c|}
\hline \multicolumn{2}{|c|}{} & Frequency & Percent & Valid Percent & Cumulative Percent \\
\hline \multirow{3}{*}{ Valid } & Male & 60 & 49.6 & 49.6 & 49.6 \\
\cline { 2 - 6 } & Female & 61 & 50.4 & 50.4 & 100 \\
\cline { 2 - 6 } & Total & 121 & 100 & 100 & \\
\hline
\end{tabular}

Table 2: Types of diabetic mellitus among the respondence.

\begin{tabular}{|c|c|c|c|c|c|}
\hline \multicolumn{1}{|c|}{} & Frequency & Percent & Valid Percent & Cumulative Percent \\
\hline \multirow{4}{*}{ Valid } & type 1 & 18 & 14.9 & 14.9 & 14.9 \\
\cline { 2 - 6 } & type 2 & 99 & 81.8 & 81.8 & 96.7 \\
\cline { 2 - 6 } & GDM & 3 & 2.5 & 2.5 & 99.2 \\
\cline { 2 - 6 } & other specific causes & 1 & 0.8 & 0.8 & 100 \\
\cline { 2 - 7 } & Total & 121 & 100 & 100 & \\
\hline
\end{tabular}

Table 3: Level of exercise among the patient.

\begin{tabular}{|c|c|c|c|c|c|}
\hline \multicolumn{2}{|c|}{} & Frequency & Percent & Valid Percent & Cumulative Percent \\
\hline \multirow{4}{*}{ Valid } & mild & 65 & 53.7 & 53.7 & 53.7 \\
\cline { 2 - 6 } & moderate & 43 & 35.5 & 35.5 & 89.3 \\
\cline { 2 - 6 } & heavy & 3 & 2.5 & 2.5 & 91.7 \\
\cline { 2 - 6 } & no & 10 & 8.3 & 8.3 & 100 \\
\cline { 2 - 7 } & Total & 121 & 100 & 100 & \\
\hline
\end{tabular}

Among the respondent the highest percentage of them were not suffering from skin and soft tissue infection (73.6\%), only 32(26.4 $\%$ ) were sufferings from skin and soft tissue infection (Table 4). Among the respondent, the highest percentage previously had no skin infection (86.8\%) and only $13.2 \%$ had skin infection (Table 5). Among the respondent the highest percentage of the respondents had blood sugar level about 5.7- $11.1 \mathrm{mmol} / \mathrm{L} 52.1 \%, 30.6 \%$ has 11.2- $20 \mathrm{mmol} / \mathrm{L}, 14 \%$ has $<5.6 \mathrm{mmol} / \mathrm{L}$ and $3.3 \%$ had more than 20
mmol/L (Figure 4). Among the respondent the highest percentage of the respondents had uncontrolled blood sugar about $52.1 \%$ and $47.9 \%$ ) had controlled blood sugar level. Among the respondent the highest percentage of them had fluctuated blood sugar level about (55.4\%) and $44.6 \%$ had static blood sugar level. Fluctuated blood sugar (19.8\%) occurs due to irregular oral medication, 19.8 $\%$ due to irregular oral medication, and $18.2 \%$ due to uncontrolled diet and $9.9 \%$ due to inadequate physical exercise (Table 6).

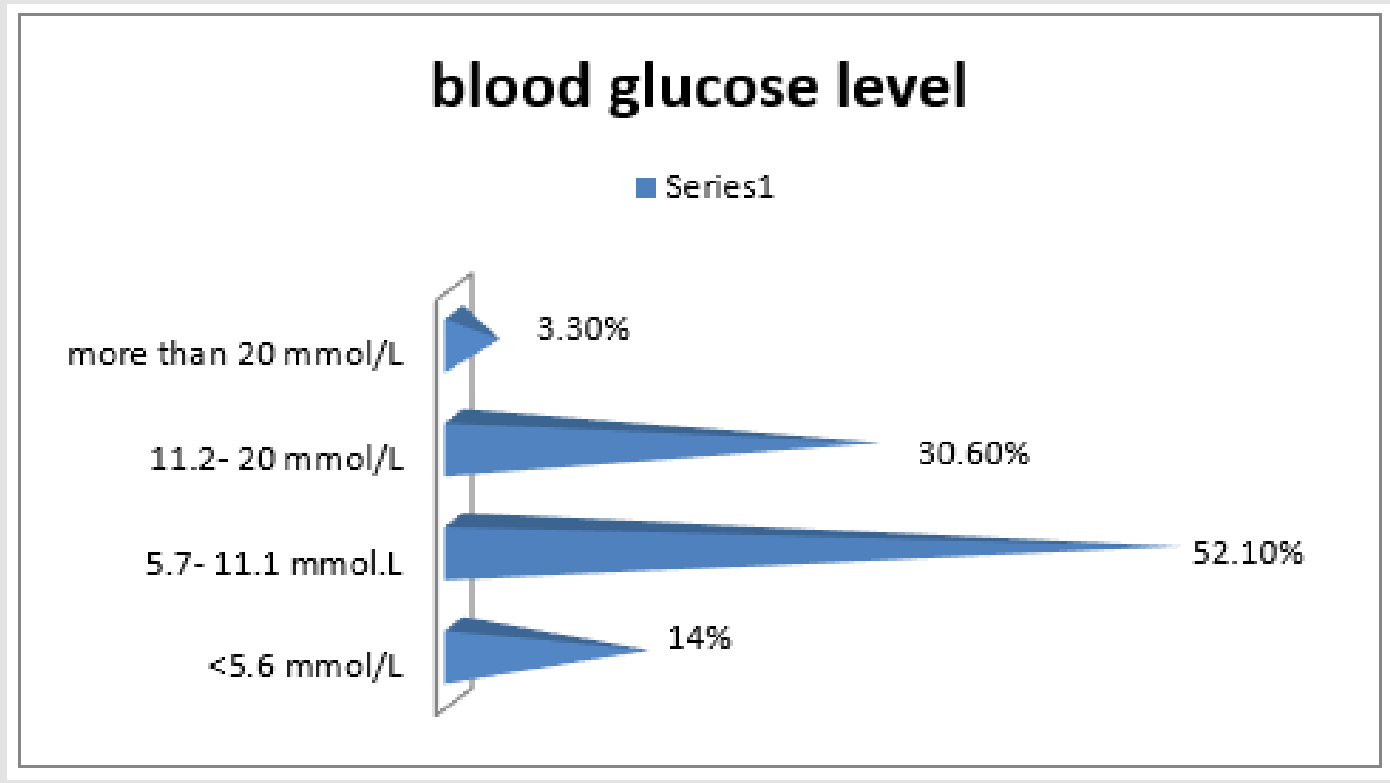

Figure 4: Level of blood sugar among the patients. 
Table 4: Respondents suffering from skin and soft tissue infection.

\begin{tabular}{|c|c|c|c|c|c|}
\hline \multicolumn{2}{|c|}{} & Frequency & Percent & Valid Percent & Cumulative Percent \\
\hline \multirow{3}{*}{ Valid } & yes & 32 & 26.4 & 26.4 & 26.4 \\
\cline { 2 - 6 } & no & 89 & 73.6 & 73.6 & 100 \\
\cline { 2 - 7 } & Total & 121 & 100 & 100 & \\
\hline
\end{tabular}

Table 5: Presence of skin infection among the respondents.

\begin{tabular}{|c|c|c|c|c|c|}
\hline \multicolumn{2}{|c|}{} & Frequency & Percent & Valid Percent & Cumulative Percent \\
\hline \multirow{3}{*}{ Valid } & yes & 16 & 13.2 & 13.2 & 13.2 \\
\cline { 2 - 6 } & no & 105 & 86.8 & 86.8 & 100 \\
\cline { 2 - 6 } & Total & 121 & 100 & 100 & \\
\hline
\end{tabular}

Table 6: Probable cause of fluctuation of diabetes mellitus.

\begin{tabular}{|c|c|c|c|c|c|}
\hline & & Frequency & Percent & Valid Percent & Cumulative Percent \\
\hline \multirow{6}{*}{ Valid } & $\begin{array}{l}\text { due to irregular oral } \\
\text { medication }\end{array}$ & 24 & 19.8 & 19.8 & 19.8 \\
\hline & irregular insulin & 22 & 18.2 & 18.2 & 38 \\
\hline & uncontrolled diet & 24 & 19.8 & 19.8 & 57.9 \\
\hline & inadequate physical exercise & 12 & 9.9 & 9.9 & 67.8 \\
\hline & skip question & 39 & 32.2 & 32.2 & 100 \\
\hline & Total & 121 & 100 & 100 & \\
\hline
\end{tabular}

Among the respondent the highest percentage of the respondents has knowledge about skin disease (62\%) and 38\% has no knowledge. Among the respondent the highest percentage of the respondents had itching about (37.2\%), and 36.4\% had scaling, $8.35 \%$ had sulcer, and 5.8\% had skin color change (Figure 5). Among the respondent the highest percentage of the respondents are visit to physician regularly about $52.95,29.8 \%$ visit irregularly to physician and 17.4 5 do not visit to physician (Figure 6). The highest percentage of the respondents has skin disease for $<15$ days about $30.6 \%, 10.7 \%$ for 1 month- 6 months,9.1\% for $6-30$ days and $8.3 \%$ for more than 6 months. $41.3 \%$ skip this question because they had no skin disease (Figure 7). The highest percentage of the respondents taking anti-fungal 37.3\%, 17.4\% taking antibacterial,
8\% antiparasitic and $1.7 \%$ antivirals. And $43 \%$ patients skip this question because they have no skin disease (Figure 8). The highest percentage of the respondents took local medication about $35.5 \%$, $19 \%$ took systemic medicine and 5.8 took both systemic and local medicine. $39.7 \%$ skip this question because they have no skin disease (Figure 9). Among the respondent the highest percentage had no infection (40\%), 23\% had eye disease, $14 \%$ kidney disease, $9 \%$ UTI, 7\% respiratory infection and $7 \%$ had oral infection (Figure 10).

The above Table 7 shows that there is no significant relationship between types of diabetic mellitus and skin infection. monthly income of the family and parents wish to send to the school, x2(1, $\mathrm{N}=121)=3.608, \mathrm{p}=.729$.

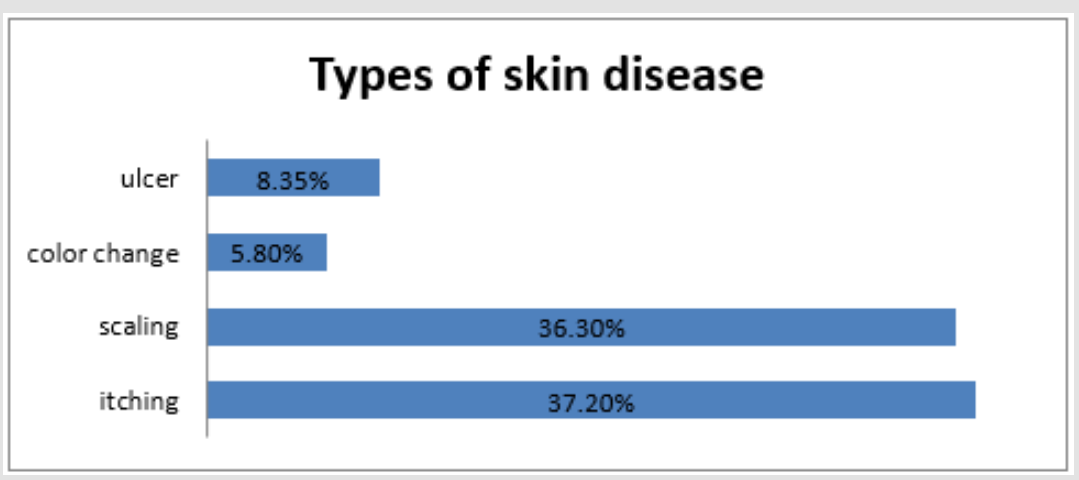

Figure 5: Types of skin diseases among the respondents. 


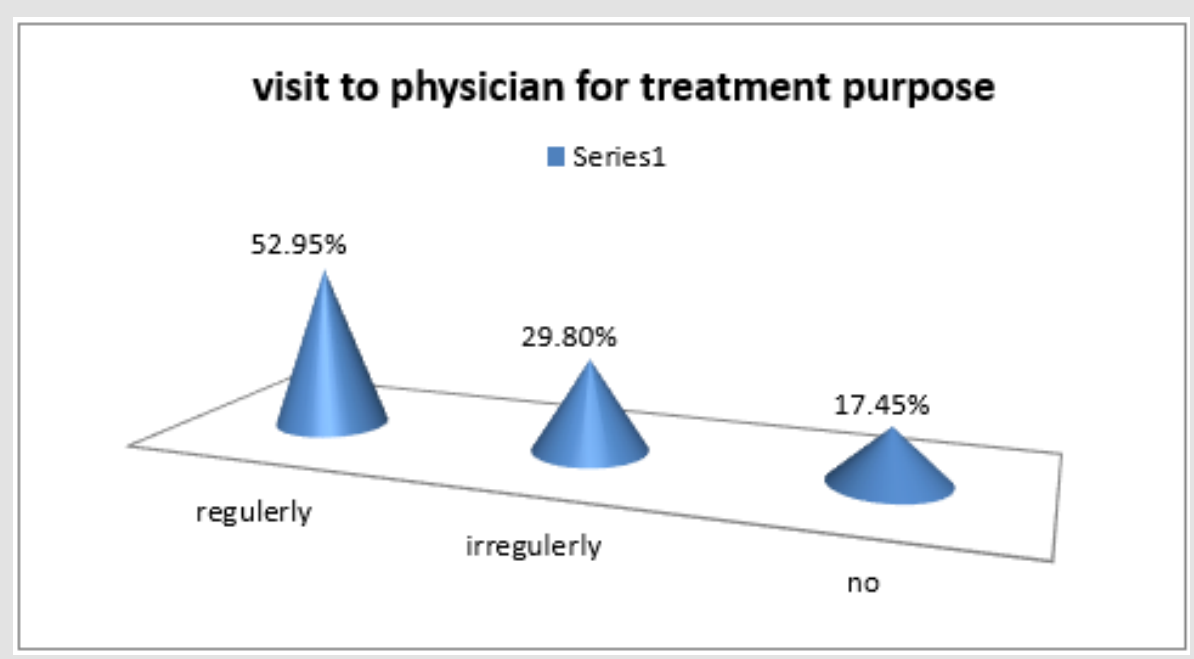

Figure 6: Visit to physician for treatment purpose.

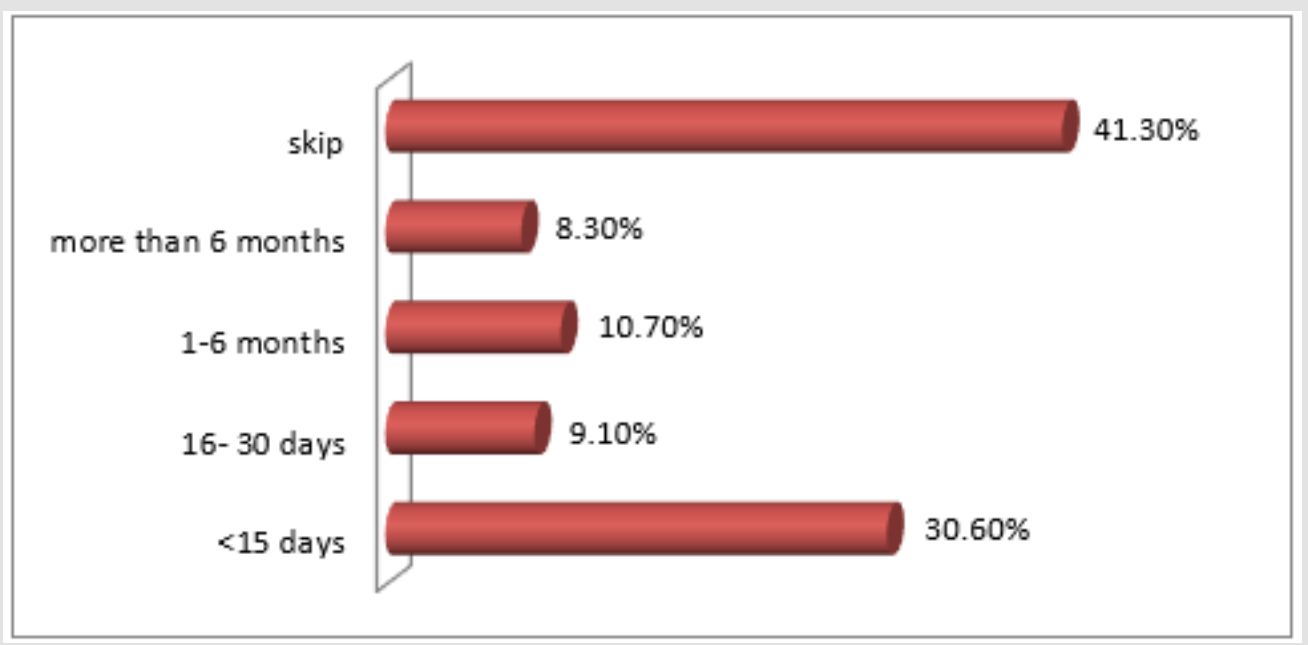

Figure 7: How long the respondents are disease suffering for skin.

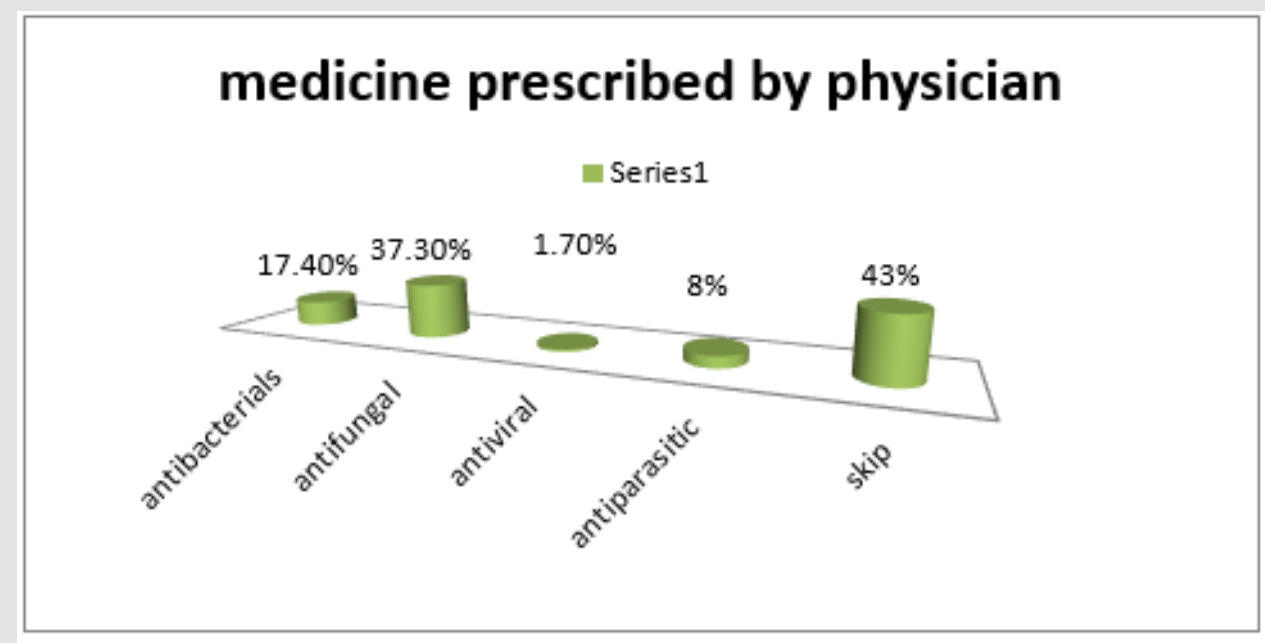

Figure 8: Medicine prescribe by physician to the respondents. 


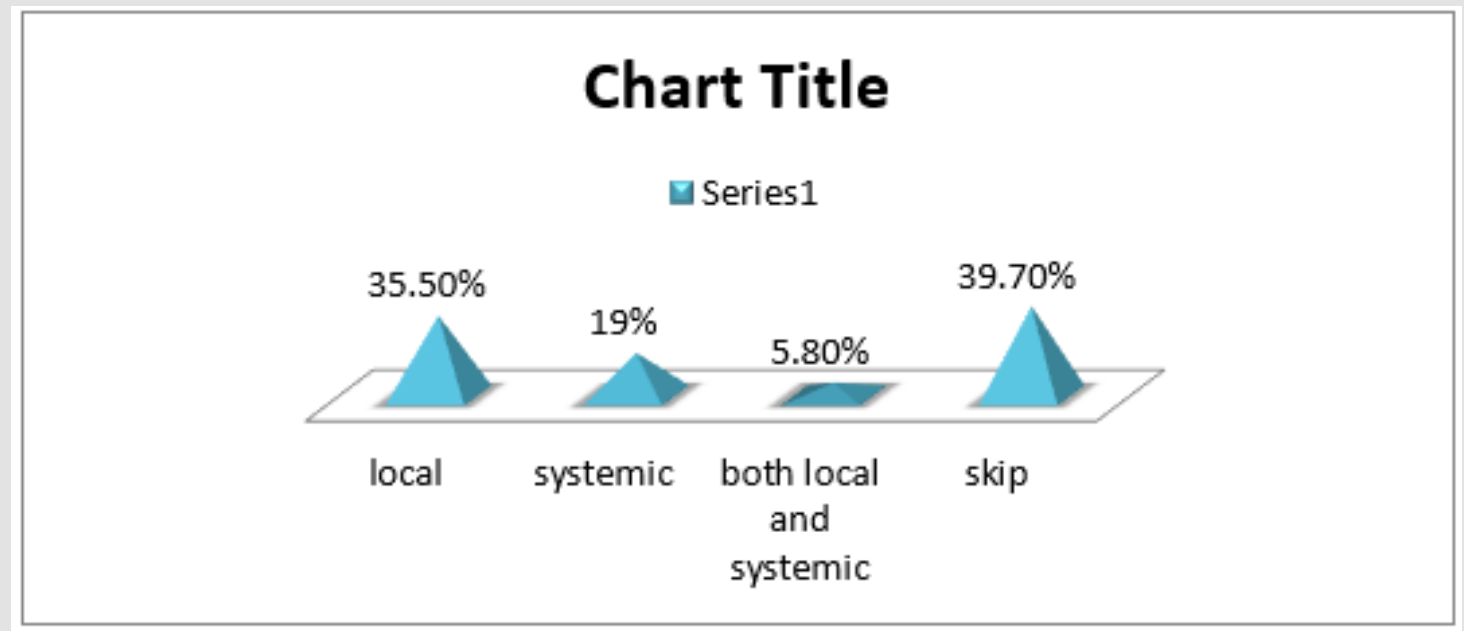

Figure 9: Medicine prescribe by physician to the respondents.

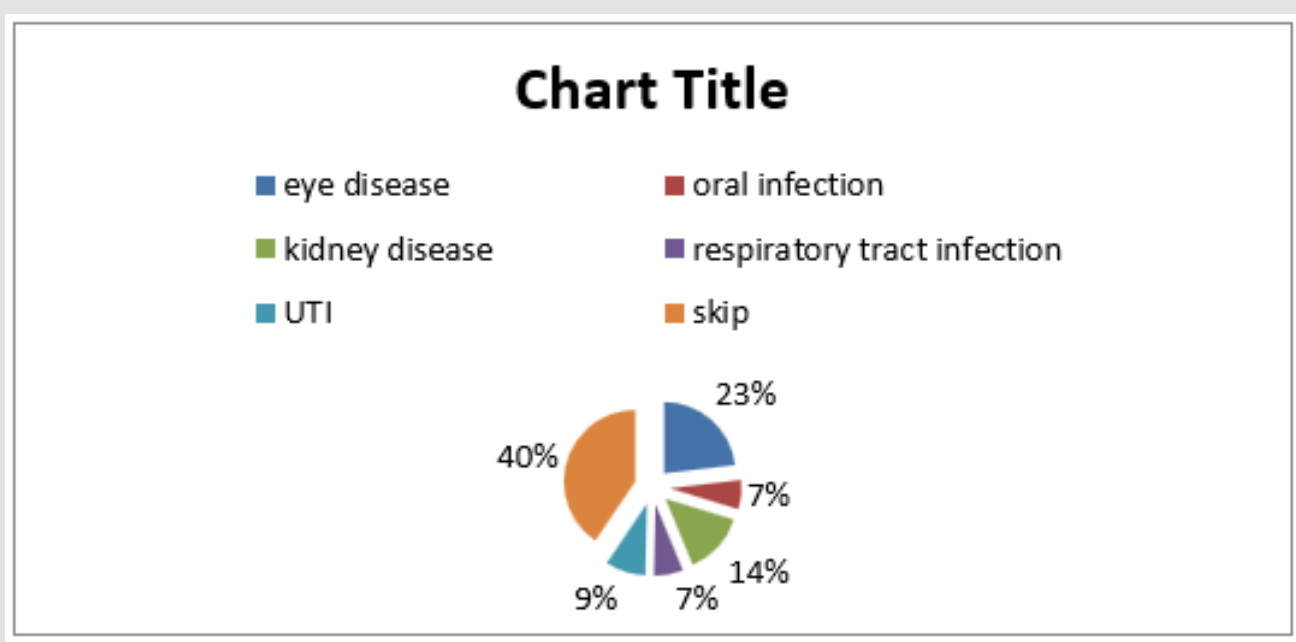

Figure 10: Type of soft tissue infection the patient suffers.

Chi-Square Tests.

\begin{tabular}{|c|c|c|c|}
\hline & Value & df & Asymp. Sig. (2-sided) \\
\hline Pearson Chi-Square & $3.608 \mathrm{a}$ & 6 & 0.729 \\
\hline Likelihood Ratio & 3.349 & 6 & 0.764 \\
\hline Linear-by-Linear Association & 0.791 & 1 & 0.374 \\
\hline N of Valid Cases & 121 & & \\
\hline
\end{tabular}

Table 7: Association between types of diabetic mellitus and skin infection.

\begin{tabular}{|c|c|c|c|c|c|c|}
\hline \multirow{2}{*}{} & \multicolumn{4}{|c|}{ Cases } \\
\cline { 2 - 7 } & \multicolumn{2}{|c|}{ Valid } & \multicolumn{2}{c|}{ Missing } & \multicolumn{2}{c|}{ Total } \\
\cline { 2 - 7 } & N & Percent & N & Percent & N & 121 \\
\hline $\begin{array}{c}\text { Types of diabetic mellitus * types of } \\
\text { soft tissue infection }\end{array}$ & 72 & $59.50 \%$ & 49 & $40.50 \%$ & $100.00 \%$ \\
\hline
\end{tabular}

Note: The above table shows that there is no significant relationship between level of diabetic mellitus and soft tissue infection, $x 2(1$, $\mathrm{N}=121)=13.709, \mathrm{p}=.320$. 
Chi-Square Tests.

\begin{tabular}{|c|c|c|c|}
\hline & Value & df & Asymp. Sig. (2-sided) \\
\hline Pearson Chi-Square & $21.292 \mathrm{a}$ & 9 & 0.011 \\
\hline Likelihood Ratio & 19.885 & 9 & 0.019 \\
\hline Linear-by-Linear Association & 9.643 & 1 & 0.002 \\
\hline N of Valid Cases & 77 & & \\
\hline
\end{tabular}

Note: The above table shows that there is a significant relationship between level of diabetic mellitus and skin disease, $x^{2}(1, N=121)$ $=21.292, \mathrm{p}=.011$.

\section{Discussions}

It is an important question that the diagnosis is very important for treatment of diabetes mellitus. The exact diagnosis is needed to treat the disease. If it is diagnosed, then the treatment protocol is difference. Among the respondent the highest percentage of the respondent's sufferings from type- 2 diabetic mellitus about 99(81.8\%),18 (14.9\%) sufferings from type- 1 diabetic mellitus and rest $1 \%$ sufferings from other specific causes. The invasive bacterial infections like Group B streptococcus have also been associated with DM. Some studies record Group B streptococcal disease in number of pregnant adults $[22,23]$. Skin, soft tissue and bone (cellulites, foot ulcers and decubitus ulcers) are the frequently infected areas in Group B streptococcus infection.

The risk of Group B streptococcal infections was found to be increased with age [24]. Staphylococcus aureus is a major pathogen implicated in diabetic foot infections [9,25]. Staphylococcal folliculitis or skin abscesses are counted as the most common bacterial infections in uncontrolled diabetes (Klingelhoets et al. 2015) [26,27]. Acute and Invasive ("malignant") otitis externa is a quite rare but potentially fatal infection of the external auditory canal and skull. It mainly involves inflammation of the ear canal [28]. Pseudomonas aeruginosa is the causative organism in the vast majority of cases. The acute form is caused primarily by P. aeruginosa and S. aureus. Acute otitis externa manifests with Unrelenting pain and rapid onset of ear canal inflammation, resulting in otalgia, itching, canal edema, canal erythema, and otorrhea.

The perineum, trunk, abdomen and upper extremities are most commonly involved in Necrotizing fasciitis $[13,29,30]$. In softtissue infections, foot infections are the most common soft tissue infections in patients with diabetes [14]. In diabetic individuals, mycotic infections might elevate the risk of manifesting diabetic foot syndrome [19]. Moreover, Glossitis, Paronychia, and onychomycosis are quite frequent [17,31-33]. In the present study, the highest percentage of the respondents had itching about $37.2 \%, 36.4 \%$ has no skin disease, $12.4 \%$ has skin ulcer, 8.35 has scaling and $5.8 \%$ has color change. Among the respondent the highest percentage of the respondents taking anti-fungal 37.3\%, 17.4\% taking antibacterial, 8\% antiparasitic and $1.7 \%$ antivirals.
It is very important for diabetes mellitus that patient should have fare knowledge about diabetes mellitus. This knowledge is very helpful for prevention as well as self-control of disease. Among the respondent the highest percentage of the respondents had knowledge about diabetic mellitus 118 (97.5\%) and rest 3(2.5\%) has no knowledge about diabetic mellitus. Among the respondent the highest percentage of the respondents heard about diabetic mellitus from physician about $63.6 \%, 19.8 \%$ from local doctor, 9.9\% from health worker and $6.6 \%$ from any communication media. Among the respondent the highest percentage of the respondents live in nuclear family about $70.2 \%, 27.3 \%$ lives in joint family and rest $2.5 \%$ lives in extended family.

It is an important question that the diagnosis is very important for treatment of diabetes mellitus. The exact diagnosis is needed to treat the disease. If it is diagnosed, then the treatment protocol is difference. Among the respondent the highest percentage of the respondent's sufferings from type- 2 diabetic mellitus about $99(81.8 \%), 18$ (14.9\%) sufferings from type- 1 diabetic mellitus and rest $1 \%$ sufferings from other specific causes.

\section{Conclusion}

Diabetes mellitus is one of the chronic deadly diseases worldwide. The complication of this disease is mainly the burden. Skin and soft tissue infection is most common complication of this disease [34-36]. Diabetic patient is more porn to infection by various organisms such as fungus bacteria, virus, parasite etc. The study reveals that, within 121 respondents, most of the diabetic patients had skin and soft tissue infection and the patients who had uncontrolled blood glucose level they were frequently experienced of this complication [37]. The lack of knowledge and also unhealthy practices are also a cause of skin and soft tissue infection among diabetic patients. Skin disease is more frequently occur among the patients whose blood glucose level was chronic and uncontrolled [38]. The prevalence of diabetic mellitus is increasing day by day and is the second cause of death worldwide. Due to its complications, the condition will be more dangerous if we cannot prevent the DM as well as control of blood sugar level of patients. That may cause various types of health complications and threatened our life [3943]. 


\section{Acknowledgement}

I also like to express my sincere, deepest and heartfelt gratitude to my Supervisor and the Faculty Public Health Department and faculty members who permitted and supported me to conduct this research. This research would not have been possible without support from the people of Faridpur diabetic Association Medical College, Hospital. They help me to interview the participants for the purpose of the study. Most importantly,

\section{Ethical Consideration}

Formal approval was obtained from concerned authority of Faridpur Diabetic Association Medical College Hospital, Faridpur.

\section{References}

1. Roberts Jacob (2015) Sickening sweet. Distillations 1(4): 12-15.

2. Laios K, Karamanou M, Saridaki Z, Androutsos G (2012) Aretaeus of Cappadocia and the first description of diabetes. Hormones 11 (1): 109113.

3. (2016) World Health Organization, Global Report on Diabetes. Geneva, 2016.

4. Shi, Yuankai, Hu, Frank B (2014) The global implications of diabetes and cancer. The Lancet. 383 (9933): 1947-1948.

5. (2016)"Annual Report 2014" (PDF). IDF. International Diabetes Federation. Retrieved 13 July 2016. IDF DIABETES ATLAS (PDF) $\left(6^{\text {th }}\right.$ Edn.). International Diabetes Federation, 2013, p. 7. ISBN 2930229853.

6. Mathers CD, Loncar D (2006) Projections of global mortality and burden of disease from 2002 to 2030. PLoS Med 3 (11): e442.

7. Wild S, Roglic G, Green A, Sicree R, King H (2004) Global prevalence of diabetes: Estimates for the year 2000 and projections for 2030. Diabetes Care 27 (5): 1047-1053.

8. Knip M, Virtanen SM, Akerblom HK; Infant feeding and the risk of type 1 diabetes Am J Clin.

9. Mayser P, Hensel J, Thoma W, Podobinska M, Geiger M, et al. (2004) Prevalence of fungal foot infections in patients with diabetes mellitus type 1 - underestimation of moccasin-type tinea. Exp Clin Endocrinol Diabetes 112: 264-268.

10. Muller L, Gorter KJ, Hak E, Goudzwaard WL, Schellevis FG, et al. (2005) Increased risk of common infections in patients with type 1 and type 2 diabetes mellitus. Clin Infect Dis 41: 281-288.

11. Tuazon CU, Perez A, Kishaba T, Sheagren JN (1975) Staphylococcus aureus among insulin-injecting diabetic patients. An increased carrier rates. JAMA 231: 1272 .

12. Johansson L, Thulin P, Low DE, Norrby-Teglund A (2010) Getting under the skin: the immunopathogenesis of Streptococcus pyogenes deep tissue infections. Clin Infect Dis 51: 58-65

13. Rubin Grandis J, Branstetter BF $4^{\text {th }}$, Yu VL (2004) The changing face of malignant (necrotising) external otitis: clinical, radiological, and anatomic correlations. Lancet Infect Dis 4: 34-39.

14. Cheng NC, Tai HC, Chang SC, Chang CH, Lai HS (2015) Necrotizing fasciitis in patients with diabetes mellitus: clinical characteristics and risk factors for mortality. BMC Infect Dis 15: 417.

15. Sentochnik DE (1995) Deep soft-tissue infections in diabetic patients. Infect Dis Clin North Am 9: 53-64.
16. Casqueiro J, Casqueiro J, Alves C (2012) Infections in patients with diabetes mellitus: A review of pathogenesis. Indian J Endocrinol Metab 16 Suppl 1: S27-36.

17. Saifullah, Mujtaba G (2009) Diabetic's skin: a storehouse of infections. J Pak Assoc Derma 19: 34-37.

18. Hsiao YC, Tsan KW, Wang TY (2002) Rhinocerebral mucormycosis in Diabetes: A Case Report. J Intern Med Taiwan 13: 160-164.

19. Coppieters KT, Boettler T, Von Herrath M (2012) Virus infections in type 1 diabetes. Cold Spring Harb Perspect Med 2: a007682.

20. Edelsberg J, Taneja C, Zervos M, Haque N, Moore C, et al. (2009) Trends in US hospital admissions for skin and soft tissue infections. Emerg Infect Dis 15: 1516-1518.

21. Hersh AL, Chambers HF, Maselli JH, Gonzalez R (2009) National trends in ambulatory visits and antibiotic prescribing for skin and soft-tissue infections. Arch Intern Med 168: 1585-1591.

22. Farley MM (2001) Group B streptococcal disease in nonpregnant adults. Clin Infect Dis 33: 556-561.

23. Lauder N, Binienda J (2005) Case Study: Postsexual Penile Ulcer as a Symptom of Diabetes. Clinical diabetes 4: 191-192.

24. Schuchat A (1998) Epidemiology of group B streptococcal disease in the United States: shifting paradigms. Clin Microbiol Rev 11: 497-513.

25. Rich J, Lee JC (2005) The pathogenesis of Staphylococcus aureus infection in the diabetic NOD mouse. Diabetes 54: 2904-2910.

26. Duff M, Demidova O, Blackburn S, Shubrook J (2015) Cutaneous manifestations of diabetes mellitus. Clin Diabetes 33: 40-48.

27. Nather A, Bee CS, Huak CY, Chew JL, Lin CB, et al. (2008) Epidemiology of diabetic foot problems and predictive factors for limb loss. J Diabet Compl 22: 77-82.

28. Slattery WH $3^{\text {rd }}$, Brackmann DE (1996) Skull base osteomyelitis. Malignant external otitis. Otolaryngol Clin North Am 29: 795-806.

29. Aragon-Sanchez J, Quintana-Marrero Y, Lazaro-Martinez JL, HernándezHerrero MJ, García-Morales E, et al. (2009) Necrotizing soft-tissue infections in the feet of patients with diabetes: outcome of surgical treatment and factors associated with limb loss and mortality. Int J Lower Extremity Wounds 8: 141-146.

30. Kao LS, Knight MT, Lally KP, Mercer DW (2005) The impact of diabetes in patients with necrotizing soft tissue infections. Surg Infect (Larchmt) 6: 427-438.

31. Dang CN, Prasad YD, Boulton AJ, Jude EB (2003) Methicillin resistant Staphylococcus aureus in the diabetic foot clinic: a worsening problem: 55.

32. Jackson L (2005) Evaluating diabetes mellitus as a risk factor for community-acquired infections. Clin Infect Dis 41: 289-290.

33. Lee YT, Chou TD, Peng MY, Chang FY (2005) Rapidly progressive necrotizing fasciitis caused by Staphylococcus aureus. J Microbiol Immunol Infect 38: 361-364.

34. Pallin DJ, Egan DJ, Pelletier AJ, Espinola JA, Hooper DC, et al. (2008) Increased US emergency department visits for skin and soft tissue infections, and changes in antibiotic choices, during the emergence of community-associated methicillin-resistant Staphylococcus aureus. Ann Emerg Med 51: 291-298.

35. Sharkawy A, Low DE, Saginur R, Gregson D, Schwartz B, et al. (2002) Severe group a streptococcal soft-tissue infections in Ontario: 19921996. Clin Infect Dis 34: 454-460.

36. Shah BR and Hux JE (2003) Quantifying the risk of infectious diseases for people with diabetes. Diabetes Care 26: 510-513. 
37. Zaky DA, Bentley DW, Lowy K, Betts RF, Douglas RG (1976) Malignant external otitis: a severe form of otitis in diabetic patients. Am J Med 61 298- 302.

38. Sreeramoju P, Porbandarwalla NS, Arango J, Latham K, Dent DL, et al. (2011) Recurrent skin and soft tissue infections due to methicillinresistant Staphylococcus aureus requiring operative debridement. Am J Surg 201: 216-220.

39. (2013) "Complicated Skin and Skin Structure Infections (cSSSI's): A Comprehensive Review." American Journal of Medical and Biological Research 1, no. 4 (2013): 159-164.

\section{ISSN: 2574-1241}

DOI: 10.26717/BJSTR.2021.38.006081

Hamida Khanum. Biomed J Sci \& Tech Res

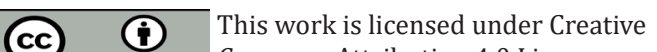

Submission Link: https://biomedres.us/submit-manuscript.php
40. Editor, Leonid Poretsky (2009) Principles of diabetes mellitus (2 ${ }^{\text {nd }}$ Edn.). New York: Springer. p. 3. ISBN 978-0-387-09840-1.

41. Global report on diabetes. World Health Organization, Geneva, 2016.

42. (2011) Public Health Agency of Canada, Diabetes in Canada: Facts and figures from a public health perspective. Ottawa.

43. (2013) The top 10 causes of death Fact sheet $\mathrm{N}^{\circ} 310$. World Health Organization. Oct 2013.

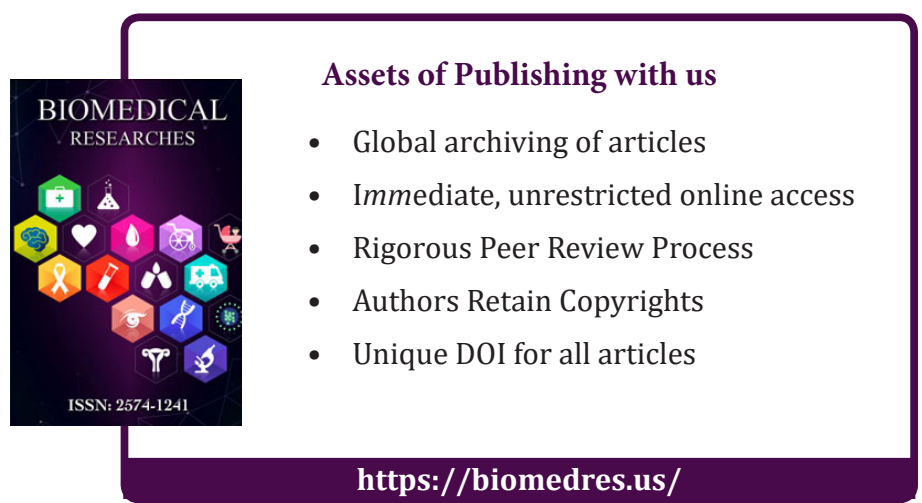

